Article

\title{
Developing Meteoric Water Lines for Iran Based on Air Masses and Moisture Sources
}

\author{
Mojtaba Heydarizad ${ }^{1}$, Ezzat Raeisi ${ }^{1}$, Rogert Sori ${ }^{2}$ and Luis Gimeno ${ }^{2, *}$ \\ 1 Department of Geology, Faculty of Sciences, Shiraz University, Shiraz 71946-84695, Iran; \\ mojtabaheydarizad@shirazu.ac.ir (M.H.); e_raeisi@yahoo.com (E.R.) \\ 2 Environmental Physics Laboratory (EphysLab), Facultad de Ciencias, Universidade de Vigo, 32004 Ourense, \\ Spain; rogert.sori@uvigo.es \\ * Correspondence: 1.gimeno@uvigo.es
}

Received: 28 August 2019; Accepted: 6 November 2019; Published: 10 November 2019

check for updates

\begin{abstract}
Iran is a semi-arid to arid country that faces a water shortage crisis. Its weather is also influenced by various air masses and moisture sources. Therefore, applying accurate stable isotope techniques to investigate Iran's precipitation characteristics and developing Iran meteoric water lines (MWLs) as an initial step for future isotope hydrology studies is vitally important. The aim of this study was to determine the MWLs for Iran by considering air masses and dominant moisture sources. The Hybrid Single-Particle Lagrangian Integrated Trajectory (HYSPLIT) model backward analysis was used to determine the trajectories of various air masses in 19 weather stations in Iran and the areas covered by them. $\delta^{18} \mathrm{O}$ and $\delta^{2} \mathrm{H}$ contents were obtained for precipitation events from 32 stations in Iran and four in Iraq. Stable isotope samples were gathered from different sources and analyzed in various laboratories across the world. Three MWLs for north of Iran, south Zagros, and west Zagros, were determined based on the locations of dominant air masses and moisture sources. The proposed MWLs were validated by comparison with fresh karstic spring isotope data across Iran. In addition, Iran main moisture sources MWLs were used to determine dominant moisture sources role in karstic springs and surface water resources recharge.
\end{abstract}

Keywords: stable isotopes; HYSPLIT model; MWL validation; karstic springs

\section{Introduction}

Isotope composition of hydrogen $\left(\delta^{2} \mathrm{H}\right)$ and oxygen $\left(\delta^{18} \mathrm{O}\right)$ of precipitation provides important fingerprint information and allows for the identification of moisture sources for precipitation, evaporated atmospheric moisture conditions, and air mass trajectory patterns [1-7]. The source of the moisture is the most important predictor of the isotope content of precipitation $[1,8]$. There are numerous numerical models to study moisture sources, but a Hybrid Single-Particle Lagrangian Integrated Trajectory (HYSPLIT) [9] model has been used in numerous stable isotope studies for tracking moisture sources of precipitation $[5,10,11]$. Some of these studies, such as [11], consider $d$-excess as reliable fingerprints to study moisture sources responsible for precipitation. Moisture released from water bodies with a high sea surface temperature (SST) and a low relative humidity normally show a high $d$-excess ( $d$-excess $=\delta^{2} \mathrm{H}-8 \times \delta^{18} \mathrm{O}$ [12]), whereas precipitation originating from water bodies with a low SST and a high relative humidity will normally have a moderate to low $d$-excess [12-14].

Stable isotope technique is a precious method to study water resources characteristics, mainly in semi-arid and arid regions like Iran. To apply the stable isotope technique, it is important to develop MWLs (as an indicator of the local precipitation). For accurate interpretation in water resource studies, stable isotope data in water supply (surface and groundwater resources) should be compared with 
local precipitation via MWLs. In most stable isotope studies in Iran, the global meteoric water line (GMWL) and the Eastern Mediterranean MWL (EMMWL) were used. However, some authors have developed local MWLs for certain regions. References [15-24] developed MWLs for Mashhad, Sirjan, Tehran, Zarivar and Marivan, Khersan, western Zagros, Shahrood, Lar National Park, northeast Iran, and North Khorasan Province, respectively. Each of these MWLs is applicable to the region for which it was developed and cannot be used in other parts of Iran because of differences in altitude, latitude, precipitation, and temperature $[25,26]$. Therefore, there is a need to develop regional Iran MWLs that can be applied to larger areas of the country. These MWLs will solve crucial obstacles regarding stable isotope studies and will be applied in the future isotope hydrology studies in Iran. In addition, to develop an MWL, the statistical approach should also be applied on precipitation isotopes data. In some studies, including $[27,28]$, a statistical approach has been used in developing MWLs.

Developing unique MWLs for Iran is not practical or reliable due to various weather conditions across Iran. Although Shamsi and Kazemi [29] tried to present a unique MWL with a limited number of samples and stations for Iran, their MWL was not reliable due to various climate conditions that govern in different parts of Iran. Therefore, the authors tried to find a way and presented a method to consider moisture sources in developing MWLs. In previous studies [30,31], it has been determined that Iran is under the influence of various air masses with different isotope characteristics. The aim of this study was to determine the sources of precipitation moisture for different regions of Iran using the HYSPLIT model backward trajectories, and also to determine various air masses' dominance zones. Iran MWLs were developed based on various air masses' dominance zones (presented by HYSPLIT) and validated by comparison with fresh karstic springs. Finally, the MWLs for the main Iran moisture sources were developed. These MWLs were used to study the role and contribution of various air masses in karstic springs and surface water recharges across Iran. The application of moisture sources MWLs to study the role and contribution of various moisture sources in karstic springs and surface water resources recharge is a new method.

\section{Iran Climatology and Weather Conditions}

Iran is known for its diverse topography and climatology. A number of large water bodies border Iran (the Caspian Sea to the north, and the Persian Gulf and Oman Sea to the south). There are also high mountain ranges in Zagros (west and southwest Iran) and Alborz (north of Iran), which surround two large deserts (Dasht-e Lut and Dasht-e Kavir in central Iran). These features influence the climate of Iran, particularly the distribution of precipitation across the country. Average precipitation in Iran is $250 \mathrm{~mm} /$ year which varies from less than $100 \mathrm{~mm} /$ year in central Iran to higher than $1000 \mathrm{~mm} / \mathrm{year}$ in the Caspian Sea coastal area [31]. There is a dry period (May to October) and a wet period (November to April) [31,32]. Four air masses including maritime polar (mP), Mediterranean (MedT), continental polar (also called the Siberian high-pressure system, cP), and continental tropical (also known as Sudan, cT) normally influence Iran in the wet period (November to April). However, the maritime tropical (mT) air mass only influences Iran in the dry period (May to October) $[25,26]$. The $\mathrm{cP}$ air mass predominantly supplies moisture from the Caspian Sea, and to a lesser extent from the Black Sea. It enters from the north and influences the north part of Iran. The $\mathrm{mP}$ air mass enters Iran from the northwest and mainly affects northwest Iran. The $\mathrm{mP}$ air mass predominantly supplies moisture from the Atlantic Ocean and the Black Sea to Iran. MedT is one of the most active air masses and affects almost all parts of Iran. The MedT air mass supplies moisture from the Mediterranean Sea and the Atlantic Ocean, and to a lesser extent the Black Sea. The $\mathrm{cP}$ and $\mathrm{mP}$ air masses dominantly influence Iran during December, January and February, while the MedT air mass dominantly influences Iran during March and April. The cT air mass affects most parts of Iran (like the MedT air mass) but affects the south most strongly. The $\mathrm{cT}$ air mass enters from the south and rarely affects areas outside of Iran. The cT air mass transports a considerable amount of moisture from the Persian Gulf, the Red Sea, and the Arabian Sea. The cT air mass has a crucial role in Iran precipitation during all of the wet period [31]. Precipitation southeast of Iran is predominantly influenced by the $\mathrm{mT}$ air mass [25]. 
The $\mathrm{mT}$ air mass supplies moisture from the Arabian Sea and the Indian Ocean to southeast and south of Iran. Karimi and Farajzadeh [32] calculated air mass trajectories for Iran using 40-year reanalysis datasets provided by the European Center for Medium Range Weather Forecasts, the US National Centers for Environmental Prediction, and the National Center for Atmospheric Research. Numerical models such as HYSPLIT and FLEXible_PARTicle dispersion model (FLEXPART) have been used widely to identify the most important moisture sources and to determine the roles of moisture sources in supplying precipitation to remote regions in several parts of the world including Iran [1,5,10,33-36].

\section{Materials and Methods}

The dominant air masses and moisture sources for 900 precipitation events (for the period of 2010 to 2016) at 19 meteorological stations were determined using 120-hour backward trajectories. A precipitation event was considered to have occurred when precipitation was $>5 \mathrm{~mm} /$ day. These trajectories were obtained using the online version of the HYSPLIT model called READY (Real Time Environmental Application and Display System) [9,37]. HYSPLIT was initially developed by the US National Oceanic and Atmospheric Administration Air Resources Laboratory in 1982 and has been improved markedly since then. The HYSPLIT model can compute simple air parcel trajectories (backwards and forwards) and complex simulations involving dispersion and deposition [37]. The position of an air parcel at a particular time is computed after wind speed, temperature, pressure, and solar radiation data have been input into the HYSPLIT model from the US National Oceanic and Atmospheric Administration "FNL" meteorological database [37].

$\delta^{18} \mathrm{O}$ and $\delta^{2} \mathrm{H}$ data were obtained from 36 precipitation sampling stations. In addition to precipitation, the isotope composition of hydrogen $\left(\delta^{2} \mathrm{H}\right)$ and oxygen $\left(\delta^{18} \mathrm{O}\right)$ of fresh karstic springs and surface water resources was also studied. All the isotope data were collected from previous publications in academic journals, PhD theses, MSc dissertations, and reports/data from the Global Network of Isotopes in Precipitation (GNIP) stations, the Karst Research Center of Iran, the Iran Regional Water Authorities, and the Iran Water Resources Institute. For event-based determination of stable isotope composition of precipitation, samples were collected in $25 \mathrm{~mL}$ polyethylene bottles after each precipitation event and they were sent to the laboratory for analyses. However, for monthly based samples, the procedure presented by the GNIP was used. To avoid and minimize evaporation in monthly samples, these samples were taken in an event-based approach according to the rainwater collected in the rain gauges after each event, and were transferred into a monthly accumulation bottle [38]. These accumulation bottles were sent to the laboratory for further stable isotope analyses. All the samples were analyzed for $\delta^{2} \mathrm{H}$ and $\delta^{18} \mathrm{O}\left(\delta(\%)=(\mathrm{R}\right.$ sample $/ \mathrm{R}$ standard -1$\left.) \times 10^{3}\right)$, where $\mathrm{R}$ is ${ }^{2} \mathrm{H} / \mathrm{H}$ or ${ }^{18} \mathrm{O} /{ }^{16} \mathrm{O}$ ratio. The isotopic composition is expressed in $\delta$ per mil, and \%o shows ${ }^{2} \mathrm{H} / \mathrm{H}$ and ${ }^{18} \mathrm{O} /{ }^{16} \mathrm{O}$ deviation from the reference VSMOW (Vienna Standard Mean Ocean Water). Analysis of the water samples was performed in several laboratories including G.G. HATCH Stable Isotope Laboratory at the University of Ottawa, Canada; Stable Isotope Laboratory at the University of Waterloo, Canada; IAEA laboratories; Federal Institute for Geosciences and Natural Resources in Hannover, Germany; Isotope Science Laboratory at the University of Calgary, Canada; National Research Center for Environment and Health (GSF), Neuherberg, Germany; the Isotope Hydrology Laboratory at Kumamoto University, Kumamoto, Japan, and several other laboratories across the world. Samples were analyzed for isotope composition of hydrogen $\left(\delta^{2} \mathrm{H}\right)$ and oxygen $\left(\delta^{18} \mathrm{O}\right)$ using isotope ratio mass spectrometer (IRMS) (Thermo Finigan, Bremen, Germany) and Los Gatos Research, Inc. (LGR) (ABB/LGR group, San Jose, CA, USA) instruments. The analytical standard uncertainties for most of the samples were $\pm 0.1 \%$ and $\pm 1 \%$ o for $\delta^{18} \mathrm{O}$ and $\delta^{2} \mathrm{H}$, respectively. 
The MWLs for Iran were developed using available isotope data and moisture sources obtained by HYSPLIT model backward trajectories. A linear regression model was used to determine the trend line between $\delta^{18} \mathrm{O}$ and $\delta^{2} \mathrm{H}$ data and develop MWLs. Linear regression was done in Microsoft Excel with Analysis ToolPack of Microsoft Office (2016) Professional Plus (Microsoft Corporation, Redmond, WA, USA) with License from the University of Vigo [39]. To understand how well the linear regression model fits the data, $R$-squared $\left(R^{2}\right)$ value was used. The higher $R^{2}$ values demonstrate smaller differences between variable data and also show how strongly the variables are correlated with each other. The developed MWLs of Iran were validated using the $\delta^{18} \mathrm{O}$ and $\delta^{2} \mathrm{H}$ contents of fresh karstic springs across the country. The application of karstic spring as a natural pluviometer has been done previously in several studies such as [40]. In addition to regression models, the Analysis of Covariance test (ANCOVA) was also applied to the precipitation and karstic springs isotope data. An ANCOVA test is just like an ANOVA test, but ANCOVA takes into account the influence of the covariate (a covariate is a variable which has influence on the dependent variable/variables). The ANCOVA test checks the effect of the covariate on the dependent variable/variables. Authors used $\mathrm{R}$ programming (R Core team, Vienna, Austria) to calculate the ANCOVA test [41].

\section{Results and Discussion}

The contributions of different air masses which caused precipitation at 19 weather stations in Iran were determined using the HYSPLIT model backward trajectories. The results are presented in Figure 1. In addition, the main air mass trajectories toward Iran and areas covered by the different air masses are also shown in this figure. Precipitation in large parts of Iran is influenced by several air masses, but in some parts of the country just one or two air masses predominate. 


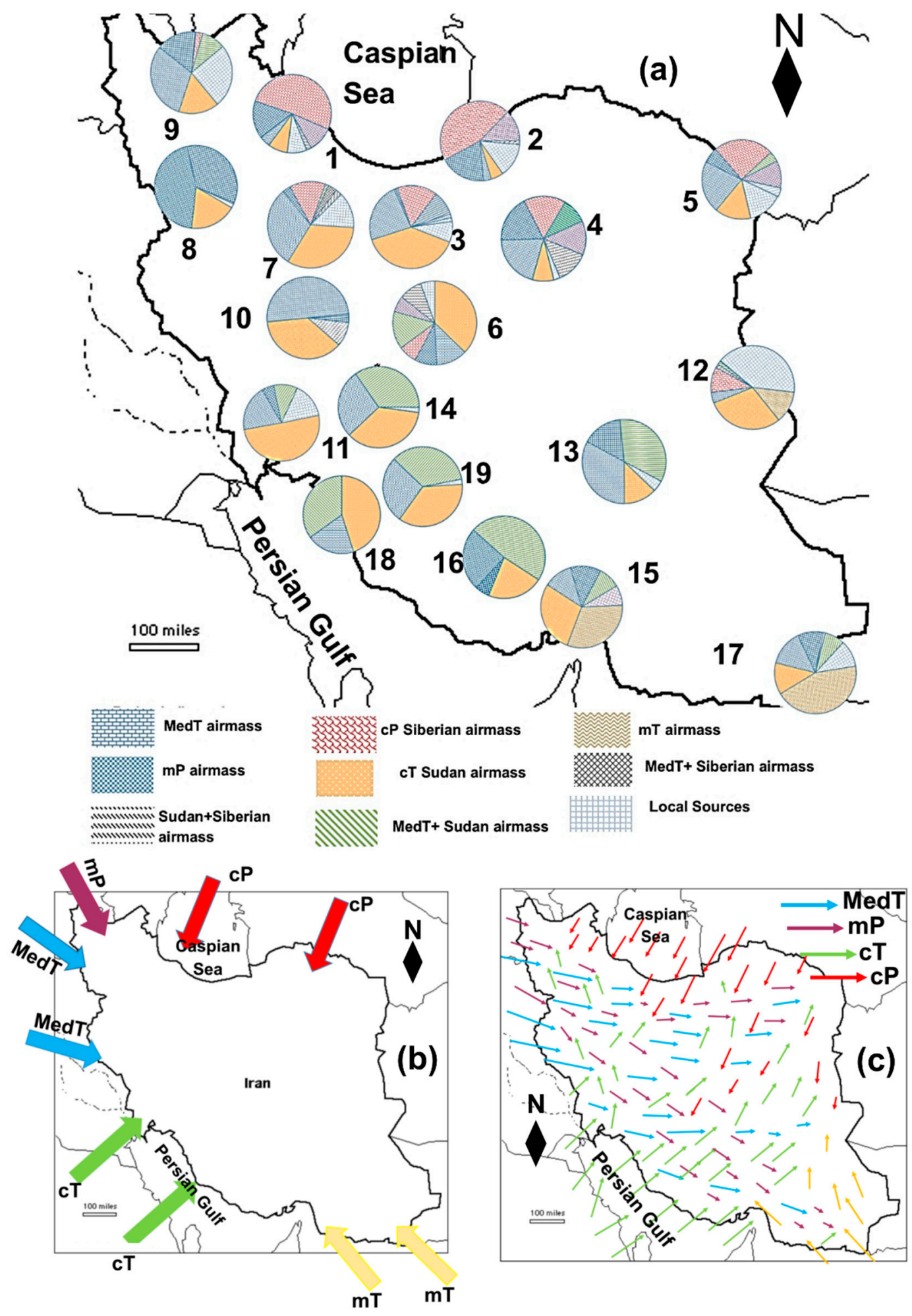

Figure 1. Contributions of different air masses causing precipitation at 19 weather stations in Iran for the period of 2010-2016. (a) The dominant air mass trajectories toward Iran. (b) The spatial distributions of these air masses across Iran. (c) The length of each arrow indicates approximate intensity of the air mass. Station names are as follows: 1 Bandar Anzali, 2 Gorgan, 3 Tehran, 4 Shahrood, 5 Mashhad, 6 Isfahan, 7 Arak, 8 Marivan, 9 Tabriz, 10 Shahrekord, 11 Ahvaz, 12 Zahedan, 13 Sirjan, 14 Samyrom, 15 Bandar Abas, 16 Darab, 17 Chabahar, 18 Bushehr, and 19 Shiraz). 


\subsection{Developing MWLs for Iran}

The mean isotope composition of hydrogen $\left(\delta^{2} \mathrm{H}\right)$ and oxygen $\left(\delta^{18} \mathrm{O}\right)$ of precipitation as well as $d$-excess, station elevation, precipitation, and air temperature for each station in Iran and Iraq are presented in Supplementary Table S1 $[15,16,18,19,21,42-57]$. The spatial distribution of the precipitation sampling stations is shown in Figure $2 \mathrm{a}$ and karstic springs sampling stations in Figure $2 \mathrm{~b}$. These stations were separated into three groups according to air mass dominance zones presented by the HYSPLIT model backward trajectories presented in Figure 1.
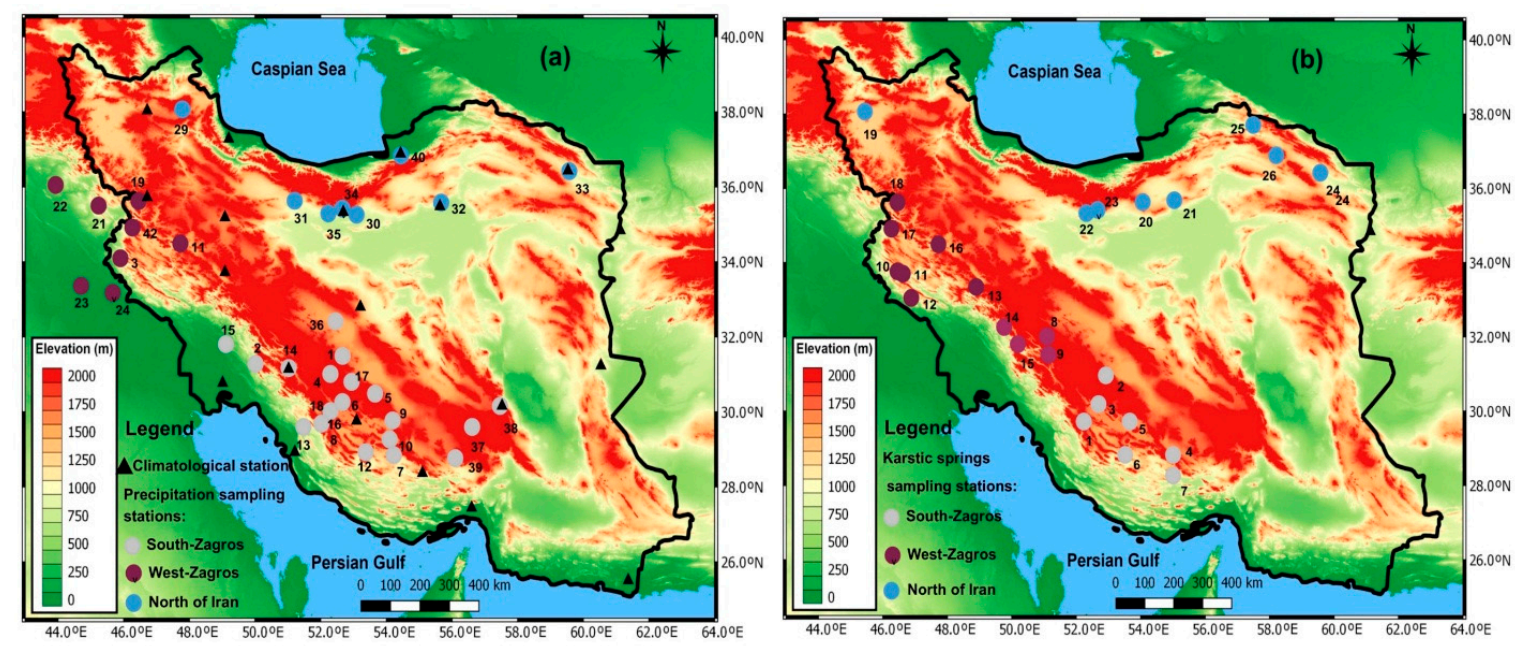

Figure 2. Climatological stations (black triangles) and precipitation sampling sites for isotope composition of hydrogen $\left(\delta^{2} \mathrm{H}\right)$ and oxygen $\left(\delta^{18} \mathrm{O}\right)$ analysis in North Iran (sky blue circles), West Zagros (brown circles) and South Zagros (gray circles) (a). Karstic springs sampling sites for isotope composition of hydrogen $\left(\delta^{2} \mathrm{H}\right)$ and oxygen $\left(\delta^{18} \mathrm{O}\right)$ analysis in Iran $(\mathbf{b})$. The geographic location, boundaries of Iran (black line), and elevation map are derived from the Hydrosheds project [58].

As Iran weather is influenced by various air masses and moisture sources, it has not been possible to develop a single MWL for Iran because the MWL and stable isotopes in precipitation mainly depend on air masses and moisture sources [1,2]. Thus, three MWLs were developed for Iran (one each for Zagros-west, Zagros-south, and north of Iran) according to the various air mass dominance zones across Iran presented in Figure 1. To understand the effect of air mass dominance zones on the developed Iran MWLs, the unique Iran MWL was developed by linear regression model and its $\mathrm{R}^{2}$ was compared with the $R^{2}$ of Iran MWLs developed based on air masses and moisture sources. Results showed that the $R^{2}$ values for Iran's unique MWL was lower than the $R^{2}$ for Iran MWLs developed based on air masses and moisture sources (Supplementary Table S2). This confirmed that developing MWLs based on air mass and moisture source dominance zones was much more accurate compared to developing a unique MWL for the whole of Iran. The linear regression model was used to develop a trend line between $\delta^{18} \mathrm{O}$ and $\delta^{2} \mathrm{H}$ data and develop MWLs. The proposed Iran MWLs and the relevant equations are shown in Figure 3.

The intercept for the North of Iran MWL $(+3.86 \%$ o) was markedly lower than the intercept for Zagros-south (14.82\%o) and Zagros-west (16.99\%o) MWLs, while the North of Iran MWL slope (7.11) was between the slope of Zagros-south (7.06) and Zagros-west (8.12), respectively. The much lower intercept and lower slope of the North of Iran MWL compared to the Zagros region's MWLs was due to various isotope characteristics of moisture sources that influence these regions. The higher slope of the Zagros-west MWL compared to other Iran MWLs and also GMWL $\delta{ }^{2} \mathrm{H}=(8.17 \pm 0.06)$ $\delta^{18} \mathrm{O}+(10.35 \pm 0.65)[59]$ was due to high relative humidity in this region. This region is covered by high mountains and local jungles with high average annual precipitation and relative humidity $(>85 \%)$ which is higher than the global average [31]. Furthermore, the average $d$-excess for the north of Iran stations $(9.45 \%$ o) was considerably lower than the averaged $d$-excess values for the south of 
Zagros (18.57\%o) and west of Zagros (16.31\%o), respectively. This is because the SSTs for the water bodies providing moisture to the Zagros regions (mainly the Mediterranean Sea, the Arabian Sea and the Persian Gulf) are higher during the primary evaporation stage than the SSTs for the water bodies providing moisture to the north of Iran (mainly the Caspian Sea, the Black Sea, and the Atlantic Ocean) [60].

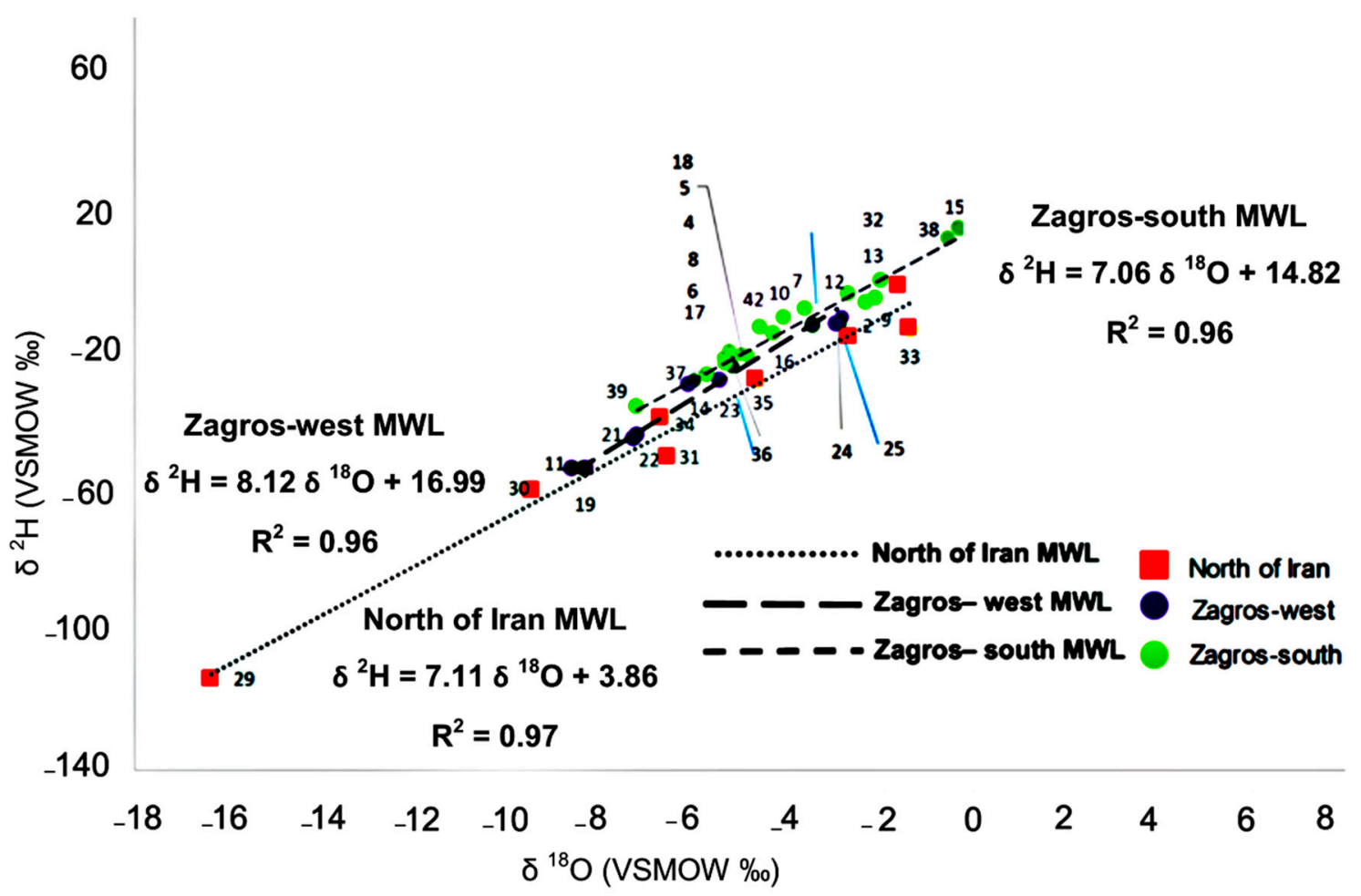

Figure 3. Average $\delta^{2} \mathrm{H}$ and $\delta^{18} \mathrm{O}$ in the sampling station's precipitation, and Iran developed meteoric water lines (MWLs).

In the ANCOVA test on the precipitation samples, air temperature, precipitation amount, and sampling station elevation were considered as covariate variables which influenced the stable isotope content of precipitation. Air mass dominance zones were considered as fixed parameters, while $\delta^{18} \mathrm{O}, \delta^{2} \mathrm{H}$ and $d$-excess were considered depended variables. After checking the first assumption of the ANCOVA test, only elevation showed $p>0.05$ and met covariate requirements (Supplementary spreadsheet S1). For the next assumption of the ANCOVA test, the homogeneity of the regression was checked. To check this assumption, air mass dominance zones were considered the fixed factor, elevation was a covariate, and $\delta^{18} \mathrm{O}, \delta^{2} \mathrm{H}$ and $d$-excess were dependent variables. The $p$ values were $>0.05$ for all the variables and homogeneity of regression was met (Supplementary spreadsheet S1). Elevation is variable which directly influences the stable isotope content of precipitation in Iran.

To validate the developed Iran MWLs, they were compared with fresh karstic springs across Iran. The $\delta^{18} \mathrm{O}, \delta^{2} \mathrm{H}$, electrical conductivity $(\mathrm{EC})$, and $d$-excess values for over 200 karstic freshwater springs are shown in Supplementary Table S3 [17,19,20,43,45,54,61-71]. Evaporation did not markedly affect the selected karstic springs, and the EC of the karstic springs water was $<1000 \mu \mathrm{S} / \mathrm{cm}$. The isotopic ratio of the karstic springs could therefore be used to check the validity of the MWLs. The proposed MWLs were validated by matching the isotopic ratio of the karstic springs with the MWLs, and the results indicated that the proposed MWLs were appropriate (Figure 4). The linear regression model was applied to trend the karstic springs water line (Supplementary Table S2). Trending lines on karstic springs showed very mild deviation from MWLs which confirmed the very low and negligible evaporation in most of the samples and the reliability of karstic springs for validation of the developed Iran MWLs. 
Studying the isotope data in karstic springs using an ANCOVA test demonstrated important results. Authors considered EC as a covariate which influenced the stable isotope content of karstic springs. Authors checked the validity of EC as a covariate and confirmed that this variable met the covariate requirements. Therefore, the first assumption of the ANCOVA test was achieved. Furthermore, the homogeneity of the regression was also tested. Karstic regions of Iran were considered as the fixed parameter, EC as the covariate variable, and $\delta^{18} \mathrm{O}, \delta^{2} \mathrm{H}$ and $d$-excess as dependent variables (Supplementary spreadsheet S1). The homogeneity of regression was met for all the dependent variables and thus two ANCOVA test assumptions were achieved. EC directly influenced the stable isotope content of karstic springs, and thus choosing the karstic springs with low EC values for validation of MWLs was a wise decision as high EC values $(>1000 \mu \mathrm{S} / \mathrm{cm})$ can influence the stable isotope content of karstic springs.
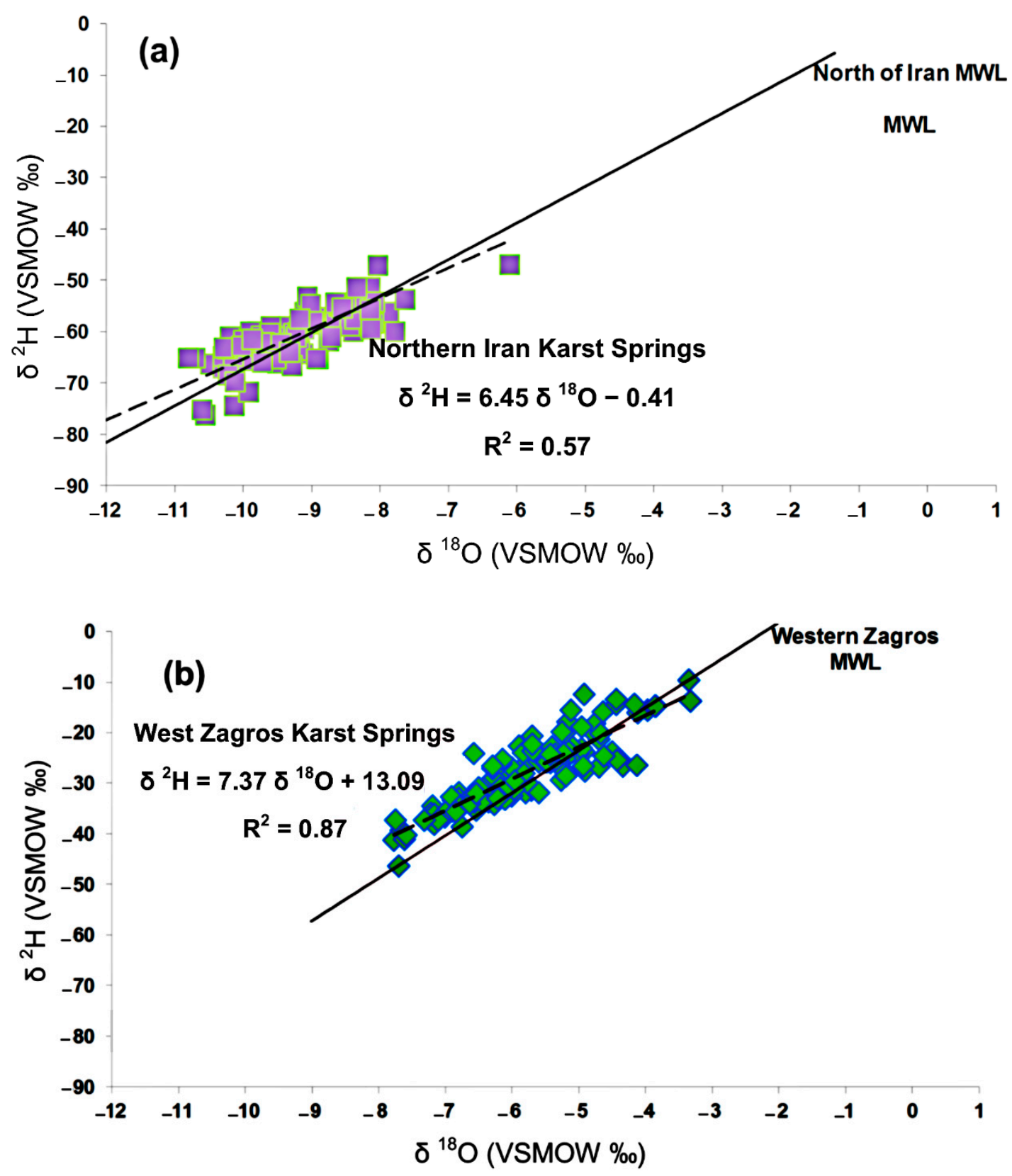

Figure 4. Cont. 


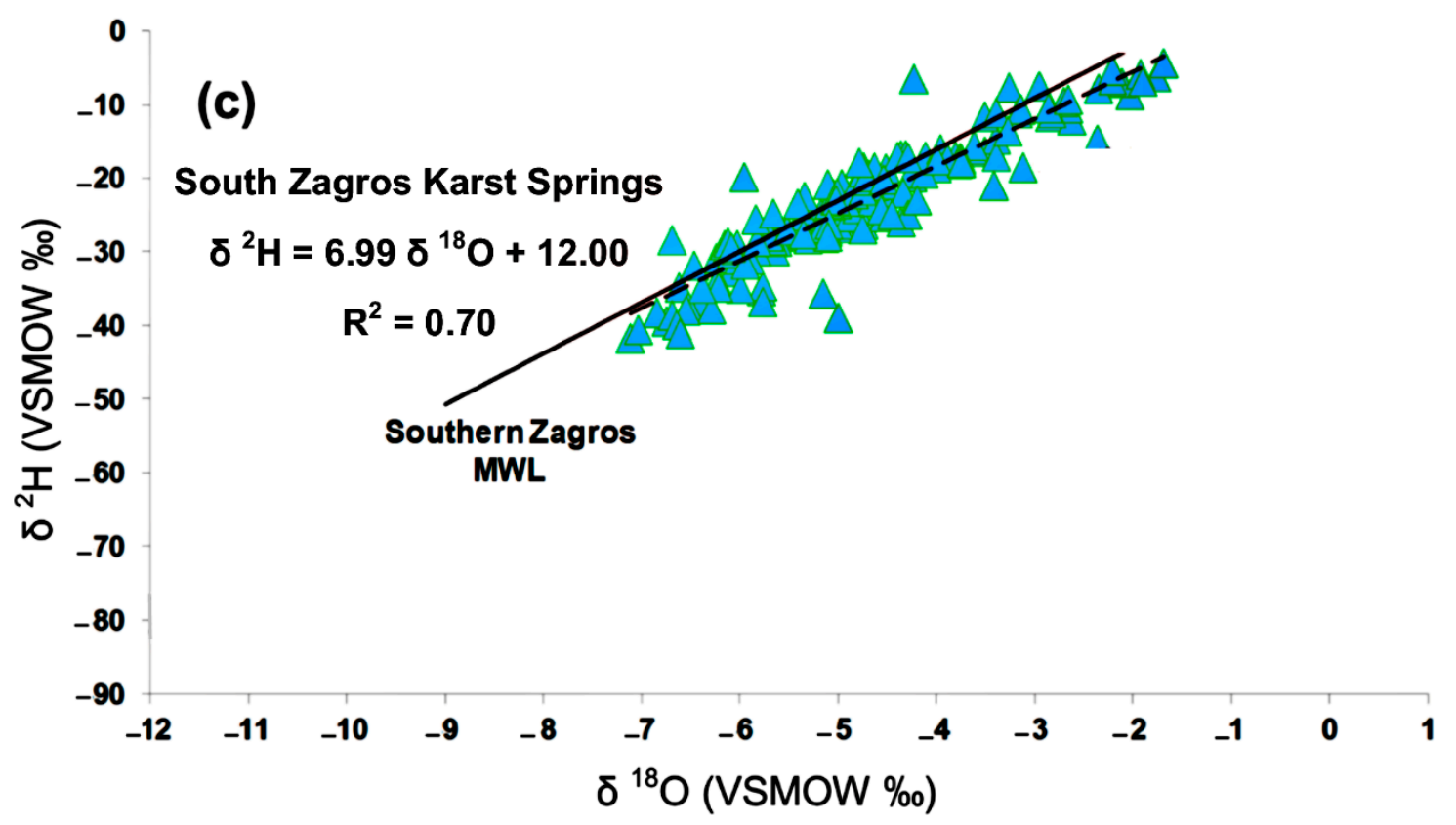

Figure 4. Karstic springs isotope values $\delta^{18} \mathrm{O}$ and $\delta^{2} \mathrm{H}$ plot on (a) North of Iran, (b) Zagros-west, and (c) Zagros-south MWLs.

The areas covered by the Iran MWLs are shown in Figure 5. No isotope data were available for coastal lowland areas along the Persian Gulf, central Iran, east and southeast Iran. Therefore, MWLs were not developed for these areas. The HYSPLIT model output indicates that the monsoon is the dominant source of precipitation for the southeast of Iran. Karachi (Pakistan) is also influenced by monsoon moisture sources [72], so the Karachi station MWL (KMWL) $\delta{ }^{2} \mathrm{H}=7.56 \delta{ }^{18} \mathrm{O}+0.34$ [73] can be used as an alternative MWL for the southeast of Iran. No alternative MWL is available for coastal areas along the Persian Gulf and central Iran. 


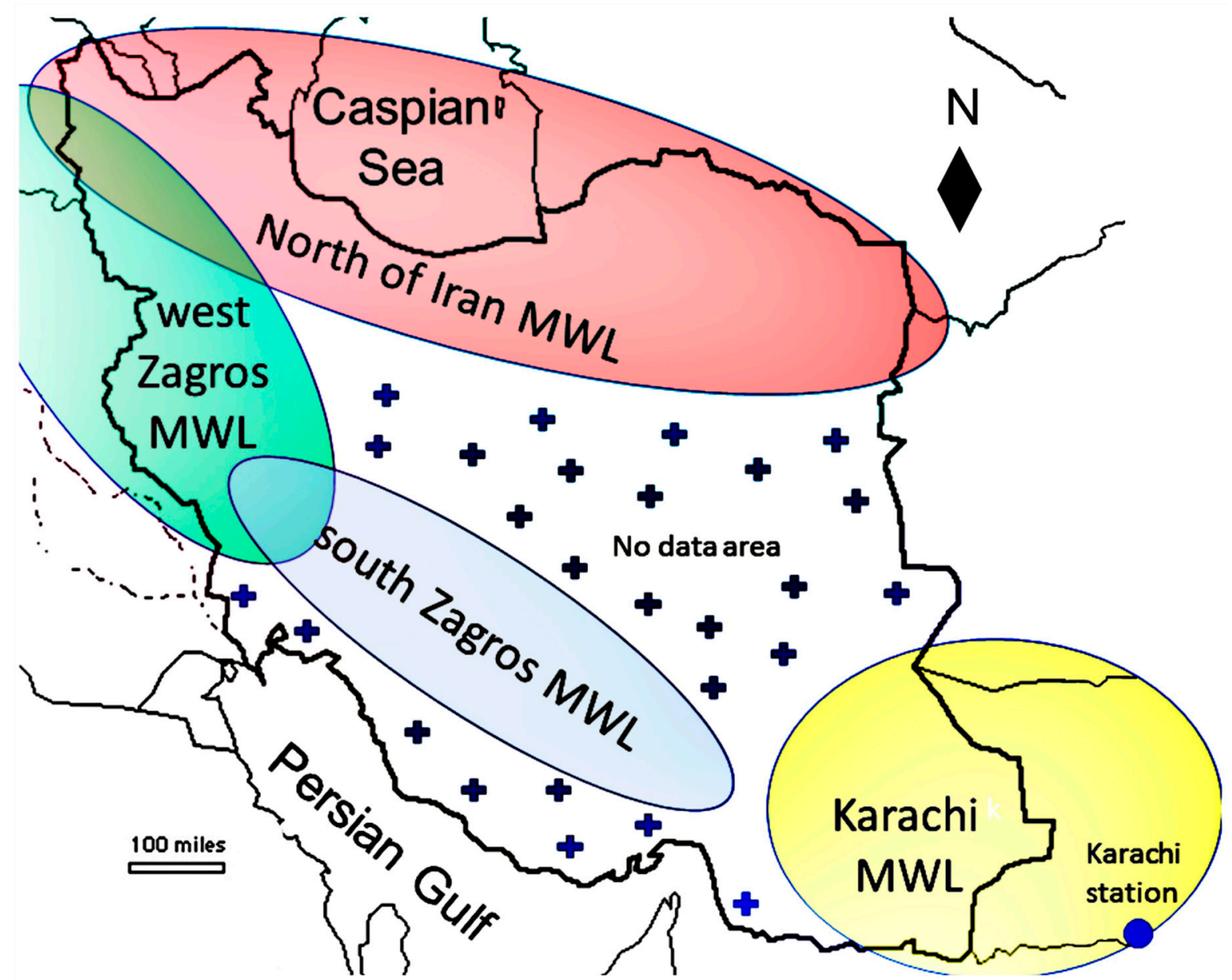

Figure 5. Map of areas covered by Iran MWLs and areas with no suggested MWLs. (The plus signs cover the areas with no suggested MWLs in Iran).

\subsection{MWLs for Specific Moisture Sources}

The HYSPLIT model output for 161 precipitation events for which isotope data were available (12 of the 32 studied stations in Iran) indicated that moisture predominantly originated from various moisture sources (mainly the Caspian Sea, the Mediterranean Sea, and the Persian Gulf). In previous studies, only the stable isotope characteristics of different moisture sources were determined [1-5,30], but herein an attempt was also made to determine MWLs for the precipitation events originated from the main moisture sources (Figure 6). These MWLs could be used to study the roles and contributions of various moisture sources in surface water and karstic springs recharge in Iran. 

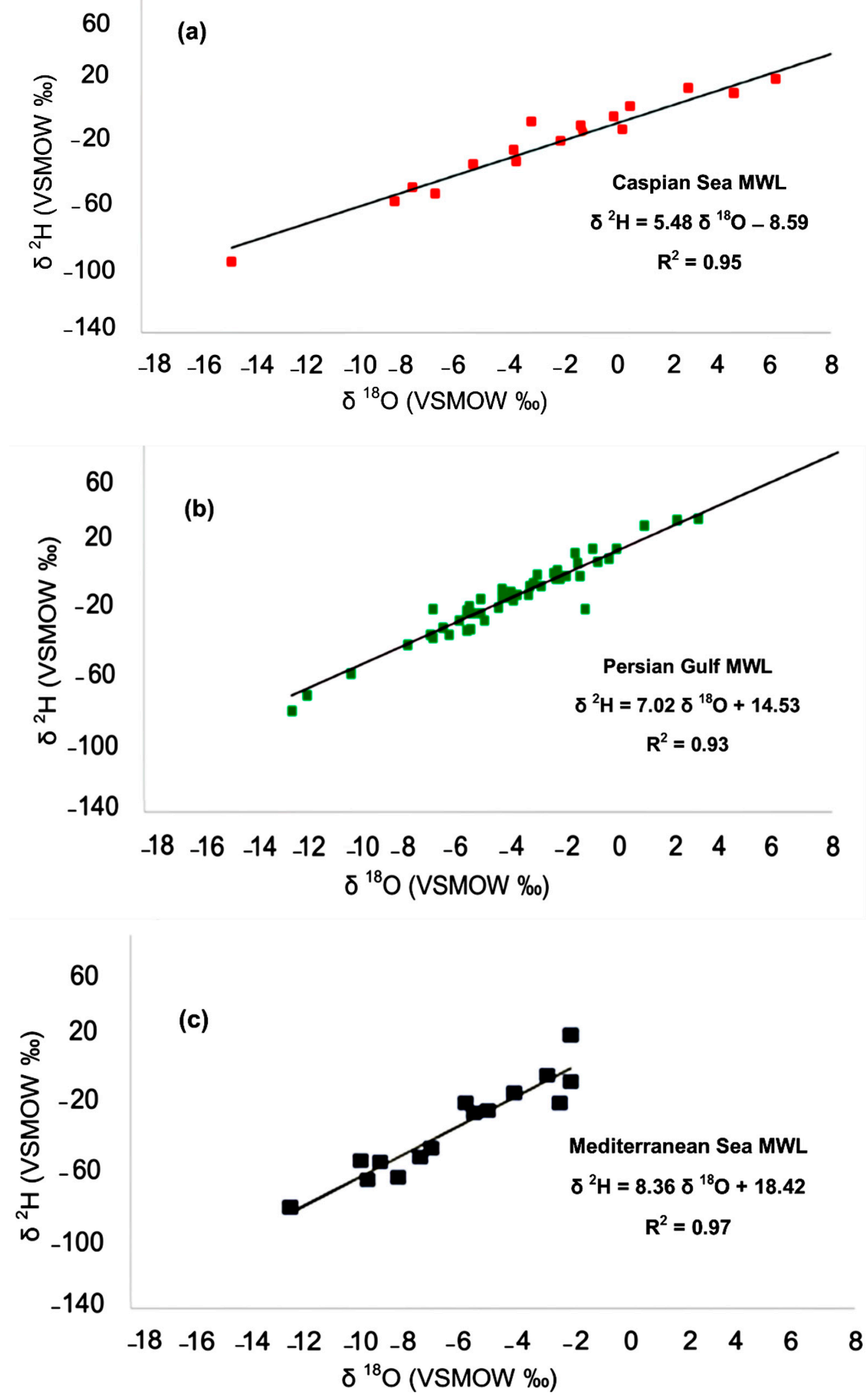

Figure 6. MWLs for specific moisture sources from the Caspian Sea (a), the Persian Gulf (b), and the Mediterranean Sea (c), all of which supply precipitation to Iran. 
The developed Iran MWLs and dominant moisture sources MWLs are shown in (Table 1). Comparing the slope and intercept of the MWLs demonstrated very valuable results. In the west Zagros region where precipitation is dominantly provided by MedT air mass, the Zagros-west MWL is similar to the Mediterranean Sea MWL in both slope and intercept. However, in the south Zagros region where precipitation is provided dominantly by MedT and cT air masses, Zagros-south MWL slope and intercept values were between the Persian Gulf and the Mediterranean Sea MWLs slope and intercept. In the north of Iran where precipitation is provided mainly by the simultaneous influence of MedT and cP air masses, the North of Iran MWL slope and intercept values were between the Mediterranean and the Caspian Sea MWL slope and intercept values.

Table 1. Regional MWLs for Iran and MWLs for specific moisture sources.

\begin{tabular}{|c|c|c|c|c|}
\hline MWL & Slope & Intercept & $\begin{array}{l}\text { Dominant Air } \\
\text { Masses }\end{array}$ & Dominant Moisture Sources \\
\hline Zagros-south & 7.06 & 14.82 & MedT \& cT & $\begin{array}{c}\text { Arabian Sea, Mediterranean Sea, } \\
\text { Persian Gulf, and continental sources }\end{array}$ \\
\hline Zagros-west & 8.12 & 16.99 & $\begin{array}{l}\text { MedT, } \\
\mathrm{cT}, \& \mathrm{mP}\end{array}$ & $\begin{array}{l}\text { Mediterranean Sea, Black Sea, Persian } \\
\text { Gulf, and continental sources }\end{array}$ \\
\hline North of Iran & 7.11 & 3.86 & $\begin{array}{l}\text { MedT, cT, } \\
\mathrm{mP}, \& \mathrm{cP}\end{array}$ & $\begin{array}{l}\text { Caspian Sea, Mediterranean Sea, } \\
\text { Black Sea, Persian Gulf, and } \\
\text { continental sources }\end{array}$ \\
\hline $\begin{array}{l}\text { Karachi MWL (KMWL) } \\
\text { for Southeast Iran }\end{array}$ & 7.56 & 0.34 & $\mathrm{mT}$ & Indian Ocean and Arabian Sea \\
\hline Caspian Sea & 5.48 & -8.59 & $\mathrm{cP}$ & Caspian Sea \\
\hline Mediterranean Sea & 8.36 & 18.42 & MedT & Mediterranean Sea and Black Sea \\
\hline Persian Gulf & 7.02 & 14.53 & $\mathrm{cT}$ & Persian Gulf \\
\hline
\end{tabular}

\subsection{The Role of Various Moisture Sources in Surface Water and Karstic Springs Recharge in Iran}

As mentioned earlier, MWLs developed for the dominant Iran moisture sources can be used in the study of moisture source contribution rate in karstic springs and surface water resources recharge. Surface water resources isotope data were collected from three dominant zones in the north of Iran, west Zagros and south Zagros [17,18,20,43,54,57,62,67,68,74-85] and presented in Supplementary Table S4. To study the role of the dominant moisture sources in surface water resources recharge, surface water samples were plotted on the Caspian Sea, the Persian Gulf and the Mediterranean Sea MWLs (Figure 7). Surface water resources in the north of Iran were closely plotted on the Caspian Sea MWL. This demonstrated the considerable role of the Caspian Sea moisture in surface water resources recharge in this region. However, the surface water resources in the south Zagros region were closely plotted on the Persian Gulf MWL. This confirmed that surface water resources in this region were dominantly under the influence of the moisture originating from the Persian Gulf. Some of the surface water resources in the south Zagros region deviated considerably from the Persian Gulf MWL due to huge evaporation effect. These surface water samples (mainly Parishan and Dasht-Arjan lakes) faced huge evaporation from their surfaces (Supplementary Table S4). Finally, plotting surface water resources on the Mediterranean Sea MWL showed that most of the surface water resources in all three dominate regions were plotted closely on this MWL. This confirmed the dominant role of the Mediterranean Sea moisture source in precipitation and surface water resources recharge in all parts of Iran. Some of the surface water resources in the north of Iran (Caspian Sea and Bazangan Lake) and also south Zagros (Parishan and Dasht-Arjan) dominantly deviated from the Mediterranean Sea MWL which was due to an intense evaporation effect on these resources (Supplementary Table S4). A linear regression model was used to develop a water line for surface water resources. The developed surface water isotope lines showed huge decline in both slope and intercept compared to both Iran MWLs and also to karstic springs isotope lines. This was due to the huge evaporation effect on surface water resources in the studied regions (Supplementary Table S4). 

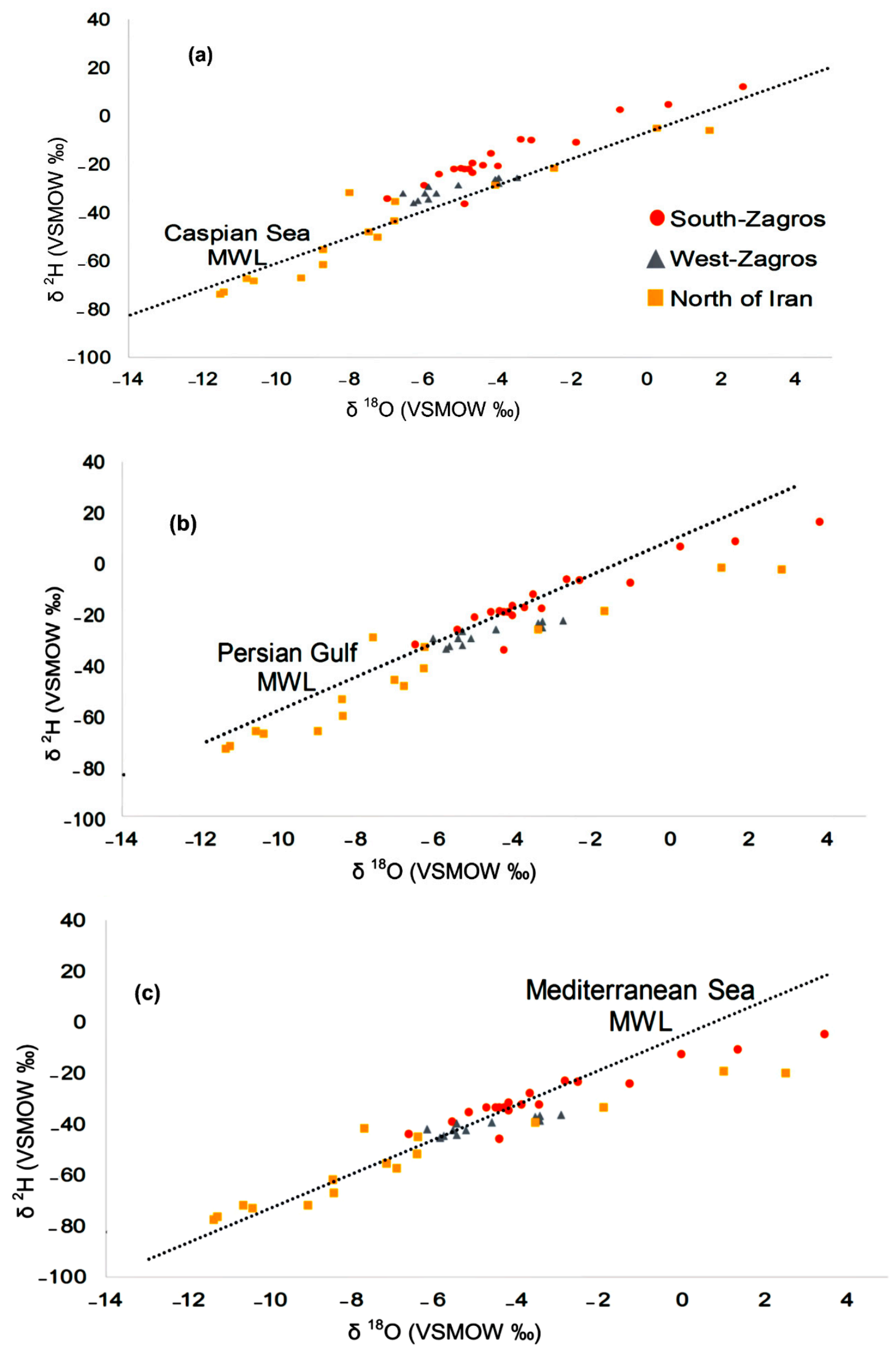

Figure 7. Plotting surface water resources $\delta^{18} \mathrm{O}$ and $\delta^{2} \mathrm{H}$ on the Caspian Sea (a), the Persian Gulf (b), and the Mediterranean Sea (c) MWLs. (The Mediterranean Sea, the Persian Gulf, and the Caspian Sea MWLs are taken from Figure 6.). 
Plotting karstic springs on the dominant moisture sources MWL also demonstrated very valuable results (Figure 8). Karstic springs in the north of Iran were plotted closely on the Caspian Sea and the Mediterranean Sea MWLs. This is due to the fact that the Caspian and Mediterranean seas moisture have a dominant role in karstic springs recharge in the north of Iran. However, karstic springs in the Zagros regions (west and south) were mainly plotted on the Persian Gulf and the Mediterranean Sea MWLs. Karstic springs in the Zagros regions are mainly recharged by the precipitation events originating from these water bodies.
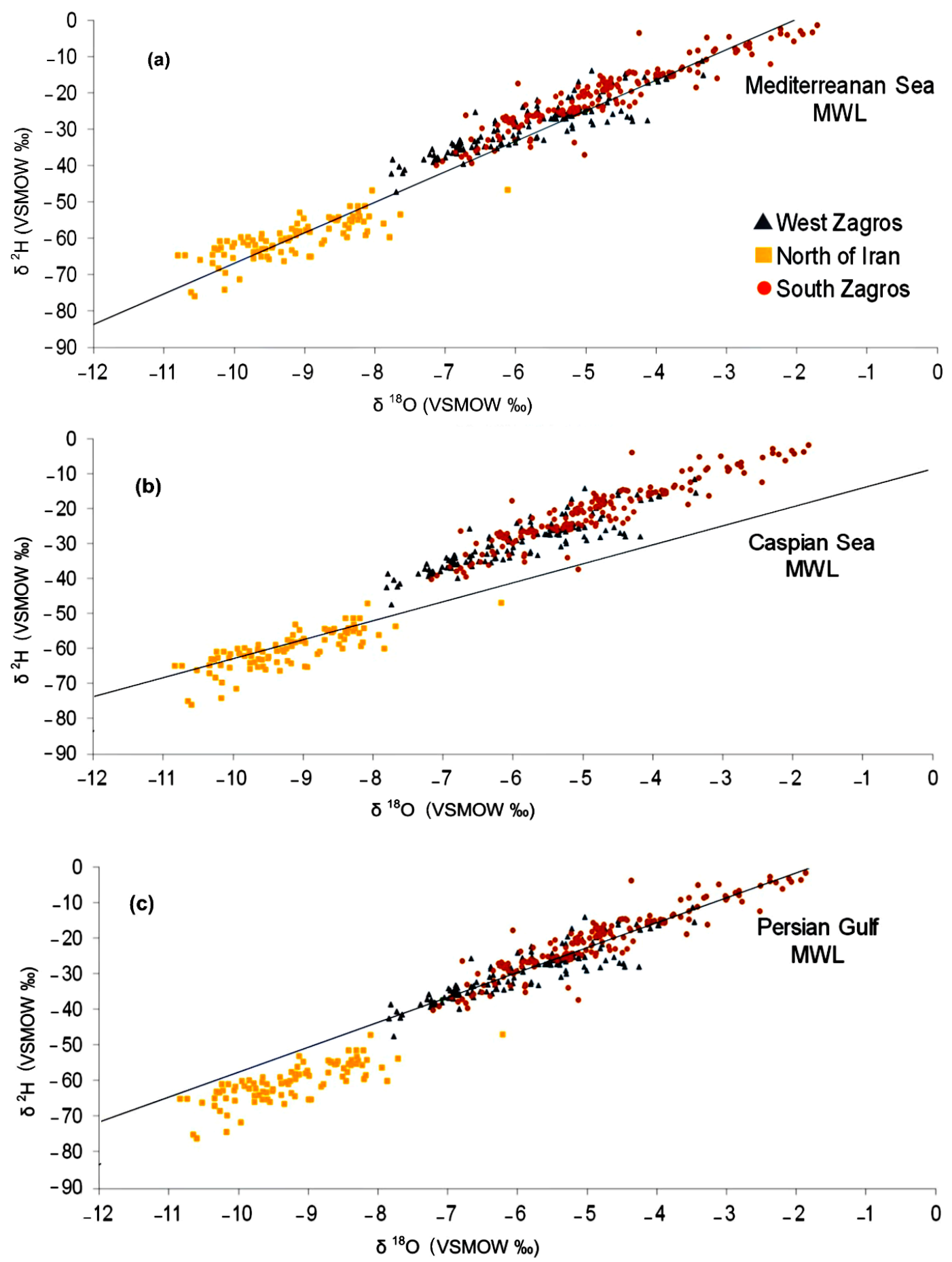

Figure 8. Plotting karstic springs $\delta^{18} \mathrm{O}$ and $\delta^{2} \mathrm{H}$ across Iran on the Mediterranean Sea (a), the Caspian Sea (b), and the Persian Gulf (c) MWLs. (The Mediterranean Sea, the Persian Gulf, and the Caspian Sea MWLs are taken from Figure 6). 
Studying the role of various moisture sources on karstic springs and surface water resources across Iran confirmed that various moisture sources dominantly recharged surface and karstic springs resources across Iran. In the north of Iran, the Caspian and Mediterranean seas influence surface and karstic springs resources, while in the Zagros regions in the west and southwest of Iran, the Persian Gulf and the Mediterranean Sea moisture have a dominant role in surface and karstic springs recharge.

\section{Conclusions}

Most parts of Iran are influenced by several air masses, but specific air masses are dominant in each part of the country. Thus, a single MWL for Iran is not appropriate. Three MWLs were developed for Iran based on the main moisture sources and air masses which influence this country (Zagros-west, Zagros-south, and North of Iran). The proposed MWLs for Iran were validated by matching karstic spring $\delta^{18} \mathrm{O}$ and $\delta^{2} \mathrm{H}$ values to the proposed MWLs. The $d$-excess values were higher for the west and south Zagros regions compared to the north of Iran, because the water bodies supplying moisture to west and south Zagros' precipitation have higher SSTs and lower humidity than those supplying moisture to the north of Iran. Furthermore, MWLs were also developed for the main Iran moisture sources (the Caspian Sea, the Mediterranean Sea, and the Persian Gulf). Plotting karstic springs and surface water resources on the main moisture sources MWLs showed that both karstic springs and surface water samples in the north of Iran were mainly plotted on the Caspian Sea and the Mediterranean Sea MWLs. However, most of the karstic springs and surface water samples were plotted on the Persian Gulf and the Mediterranean Sea MWLs in the south and west Zagros regions. The methods proposed here can be applied in other regions influenced by various air masses and moisture sources.

Supplementary Materials: The following are available online at http://www.mdpi.com/2073-4441/11/11/2359/s1, Table S1. Station elevation, precipitation depth $(\mathrm{P})$, air temperature (T), mean isotope composition of hydrogen $\left(\delta^{2} \mathrm{H}\right)$ and oxygen $\left(\delta^{18} \mathrm{O}\right)$ of precipitation, and mean $d$-excess for each studied station in Iran and Iraq; Table S2. The linear regression models for precipitation, karstic springs and surface water resources data; Table S3. Mean isotope composition of hydrogen $\left(\delta^{2} \mathrm{H}\right)$ and oxygen $\left(\delta^{18} \mathrm{O}\right)$, electrical conductivity $(\mathrm{EC})$, and $d$-excess values in karstic springs sampling stations for the regions in Iran covered by the MWLs, and the number of karst springs in each region; Table S4. Mean isotope composition of hydrogen $\left(\delta^{2} \mathrm{H}\right)$ and oxygen $\left(\delta^{18} \mathrm{O}\right)$, and $d$-excess values in surface water resources for the regions in Iran covered by the MWLs, and the number of surface water resources in each region; Spreadsheet S1: ANCOVA test results for the precipitation and karstic springs stable isotope data.

Author Contributions: Conceptualization, M.H. and E.R.; investigation, M.H. and R.S.; methodology, M.H. and L.G.; project administration, L.G. and M.H.; software, M.H., L.G. and R.S.; supervision, E.R., L.G. and R.S.; writing—original draft, M.H. and L.G.

Funding: This research received no external funding.

Acknowledgments: The support of researchers at the Iran Regional Water Authorities and researchers at the Iran Water Research Institute is greatly appreciated. Special thanks to our colleagues and students in the EPhysLab Group at the Ourense campus of Vigo University in Spain and at Shiraz University in Iran for their help and support during this study.

Conflicts of Interest: The authors declare no conflicts of interest.

\section{References}

1. Sjostrom, D.J.; Welker, J.M. The influence of air mass source on the seasonal isotopic composition of precipitation, eastern USA. J. Geochem. Explor. 2009, 102, 103-112. [CrossRef]

2. Birks, J.; EDWARDS, T.W. Atmospheric circulation controls on precipitation isotope-Climate relations in western Canada. Tellus B Chem. Phys. Meteorol. 2009, 61, 566-576. [CrossRef]

3. Lykoudis, S.P.; Kostopoulou, E.; Argiriou, A.A. Stable isotopic signature of precipitation under various synoptic classifications. Phys. Chem. Earth Parts $A / B / C$ 2010, 35, 530-535. [CrossRef]

4. Liu, Z.; Bowen, G.J.; Welker, J.M. Atmospheric circulation is reflected in precipitation isotope gradients over the conterminous United States. J. Geophys. Res. Space Phys. 2010, 115. [CrossRef] 
5. Crawford, J.; Hughes, C.E.; Parkes, S.D. Is the isotopic composition of event based precipitation driven by moisture source or synoptic scale weather in the Sydney Basin, Australia? J. Hydrol. 2013, 507, 213-226. [CrossRef]

6. Kong, Y.; Wang, K.; Li, J.; Pang, Z. Stable Isotopes of Precipitation in China: A Consideration of Moisture Sources. Water 2019, 11, 1239. [CrossRef]

7. Fan, Y.; Chen, Y.; He, Q.; Li, W.; Wang, Y. Isotopic Characterization of River Waters and Water Source Identification in an Inland River, Central Asia. Water 2016, 8, 286. [CrossRef]

8. Burnett, A.W.; Mullins, H.T.; Patterson, W.P. Relationship between atmospheric circulation and winter precipitation $\delta 18 \mathrm{O}$ in central New York State. Geophys. Res. Lett. 2004, 31, 209. [CrossRef]

9. Stein, A.F.; Draxler, R.R.; Rolph, G.D.; Stunder, B.J.B.; Cohen, M.D.; Ngan, F.; Stein, A. NOAA's HYSPLIT Atmospheric Transport and Dispersion Modeling System. Bull. Am. Meteorol. Soc. 2015, 96, 2059-2077. [CrossRef]

10. Soderberg, K.; Good, S.P.; O'Connor, M.; Wang, L.; Ryan, K.; Caylor, K.K. Using atmospheric trajectories to model the isotopic composition of rainfall in central Kenya. Ecosphere 2013, 4, 1-18. [CrossRef]

11. Juhlke, T.R.; Meier, C.; Van Geldern, R.; Vanselow, K.A.; Wernicke, J.; Baidulloeva, J.; Barth, J.A.; Weise, S.M. Assessing moisture sources of precipitation in the Western Pamir Mountains (Tajikistan, Central Asia) using deuterium excess. Tellus B Chem. Phys. Meteorol. 2019, 71, 1-16. [CrossRef]

12. Dansgard, W. Stable isotopes in precipitation. Tellus 1964, 16, 436-468. [CrossRef]

13. Gat, J.R.; Carmi, I. Evolution of the isotopic composition of atmospheric waters in the Mediterranean Sea area. J. Geophys. Res. Space Phys. 1970, 75, 3039-3048. [CrossRef]

14. Clark, I.D. Environmental Isotopes in Hydrogeology; CRC Press/Lewis Publishers: Boca Raton, FL, USA, 1997; ISBN 1566702496.

15. Mohammadzadeh, $\mathrm{H}$. The Meteoric Relationship for ${ }^{18} \mathrm{O}$ and ${ }^{2} \mathrm{H}$ in Precipitations and Isotopic Compositions of water resources in Mashhad Area (NE Iran). In The 1st International Applied Geological Congress; Islamic Azad University-Mashad Branch: Mashhad, Iran, 2010; pp. 555-559.

16. Jahanshahi, R. Environmental Effects of GoleGohar Iron Ore Mine on Groundwater of the Area; Shiraz University: Shiraz, Iran, 2013.

17. Heydarizad, M. Investigation of Hydrochemistry of Karde Dam and its Hydraulically Connection with Downstream Water Resources; Ferdowsi University of Mashhad: Mashhad, Iran, 2011.

18. Mohammadzadeh, H.; Ebrahimpour, S. Application of stable isotopes and hydrochemistry to investigate sources and quality exchange Zarivar catchment area. J. Water Soil 2012, 26, 1018-1031.

19. Mohammadi, Z. Method of Leakage Study at Karst Dam Site, the Zagros Region; Shiraz University: Shiraz, Iran, 2006.

20. Osati, K.; Koeniger, P.; Salajegheh, A.; Mahdavi, M.; Chapi, K.; Malekian, A. Spatiotemporal patterns of stable isotopes and hydrochemistry in springs and river flow of the upper Karkheh River Basin, Iran. Isot. Environ. Health Stud. 2014, 50, 169-183. [CrossRef]

21. Kazemi, G.A.; Ichiyanagi, K.; Shimada, J. Isotopic characteristics, chemical composition and salinization of atmospheric precipitation in Shahrood, northeastern Iran. Environ. Earth Sci. 2015, 73, 361-374. [CrossRef]

22. Shamsi, A.; Karami, G.H.; Hunkeler, D.; Taheri, A. Isotopic and hydrogeochemical evaluation of springs discharging from high-elevation karst aquifers in Lar National Park, northern Iran. Hydrogeology 2019, 27, 655. [CrossRef]

23. Mohammadzadeh, H.; Heydarizad, M. $\delta^{18} \mathrm{O}$ and $\delta^{2} \mathrm{H}$ characteristics of moisture sources and their role in surface water recharge in the north-east of Iran. Isot. Environ. Health Stud. 2019, 1-16. [CrossRef]

24. Bagheri, R.; Bagheri, F.; Karami, G.H.; Jafari, H. Chemo-isotopes $\left({ }^{18} \mathrm{O} \&{ }^{2} \mathrm{H}\right)$ signatures and HYSPLIT model application: Clues to the atmospheric moisture and air mass origins. Atmos. Environ. 2019, 215, 116892.

25. Alijani, B. Iran Climatology, 5th ed.; Payam Nour Publication: Tehran, Iran, 2000; ISBN 978-964-455-621-0.

26. Heydarizad, M.; Raeisi, E.; Sori, R.; Gimeno, L.; Nieto, R. The Role of Moisture Sources and Climatic Teleconnections in Northeastern and South-Central Iran's Hydro-Climatology. Water 2018, 10, 1550. [CrossRef]

27. Crawford, J.; Hughes, C.E.; Lykoudis, S. Alternative least squares methods for determining the meteoric water line, demonstrated using GNIP data. J. Hydrol. 2014, 519, 2331-2340. [CrossRef] 
28. Boschetti, T.; Cifuentes, J.; Iacumin, P.; Selmo, E. Local Meteoric Water Line of Northern Chile ( $\left.18^{\circ} \mathrm{S}-30^{\circ} \mathrm{S}\right)$ : An Application of Error-in-Variables Regression to the Oxygen and Hydrogen Stable Isotope Ratio of Precipitation. Water 2019, 11, 791. [CrossRef]

29. Shamsi, A.; Kazemi, G.A. A review of research dealing with isotope hydrology in Iran and the first Iranian meteoric water line. JGeope 2014, 4, 73-86.

30. Heydarizad, M.; Raeisi, E.; Sori, R.; Gimeno, L. An overview of the atmospheric moisture transport effect on stable isotopes $(\delta 18 \mathrm{O}, \delta 2 \mathrm{H})$ and D excess contents of precipitation in Iran. Theor. Appl. Clim. 2019, 138, 47-63. [CrossRef]

31. Heydarizad, M. Meteoric Water Lines of Iran for Various Precipitation Sources; Shiraz University: Shiraz, Iran, 2018.

32. Karimi, M.; Farajzadeh, M. Spatial and Temporal distribution of Iran's precipitation moisture. J. Geogr. Sci. Stud. 2011, 19, 109-127.

33. Ciric, D.; Stojanovic, M.; Drumond, A.; Nieto, R.; Gimeno, L. Tracking the Origin of Moisture over the Danube River Basin Using a Lagrangian Approach. Atmosphere 2016, 7, 162. [CrossRef]

34. Drumond, A.; Taboada, E.; Nieto, R.; Gimeno, L.; Vicente-Serrano, S.M.; López-Moreno, J.I. A Lagrangian analysis of the present-day sources of moisture for major ice-core sites. Earth Syst. Dyn. 2016, 7, 549-558. [CrossRef]

35. Heydarizad, M.; Raeisi, E.; Sori, R.; Gimeno, L. The Identification of Iran's Moisture Sources Using a Lagrangian Particle Dispersion Model. Atmosphere 2018, 9, 408. [CrossRef]

36. Nieto, R.; Gimeno, L.; Gallego, D.; Trigo, R. Contributions to the moisture budget of airmasses over Iceland. Meteorol. Z. 2007, 16, 37-44. [CrossRef]

37. NOAA. Available online: https://www.esrl.noaa.gov (accessed on 20 October 2019).

38. IAEA/GNIP. Precipitation Sampling Guide; International Atomic Energy Agency (IAEA): Vienna, Austria, 2014.

39. Microsoft Office (2016) Professional PLus Microsoft Excel 2016; Microsoft corporation: Redmond, WA, USA; Available online: https://www.office.com/ (accessed on 10 November 2019).

40. Minissale, A.; Vaselli, O. Karst springs as "natural" pluviometers: Constraints on the isotopic composition of rainfall in the Apennines of central Italy. Appl. Geochem. 2011, 26, 838-852. [CrossRef]

41. R core Team. R: A Language and Environment for Statistical Computing; R Foundation for Statistical Computing: Vienna, Austria, 2018; Available online: https://www.R-project.org/ (accessed on 10 November 2019).

42. Faroughi, A. Characterizing Isotopic Signature of Precipitation in Fars Province, Iran; Shiraz University: Shiraz, Iran, 2008.

43. Zarei, H.; Akhondali, A.M.; Mohammadzadeh, H.; Radmanesh, F.; Laudon, H. Runoff generation processes during the wet-up phase in a semi-arid basin in Iran. Hydrol. Earth Syst. Sci. Discuss. 2014, 11, 3787-3810. [CrossRef]

44. Karimi, H. Investigating the Oxygen-18 and Deuterium Isotope Composition of Precipitations in Western Zagros. In Proceedings of the 1st National Conference on Application of Stable Isotopes, Mashhad, Iran, 8 May 2013.

45. Rezaei, M.; Karimi, H.; Jokar, B. Studies of Kazeroon-Persian Gulf karstic basins. Karst Res. Cent. Iran 1998, 2, 75-120.

46. Ghazban, F. Geological and geochemical investigation of Damavand geothermal prospect, central Alborz mountain, northern Iran. Geotherm. Resour. Counc. Trans. 2000, 24, 229-234.

47. Nickghoujag, Y.; Mohammadzadeh, H.; Naseri, H.R. The application of stable isotopes $\left({ }^{18} \mathrm{O}\right.$ and $\left.{ }^{2} \mathrm{H}\right)$ to determine the role of surface water in shallow groundwater resources in Gorgan rood basin. In Proceedings of the Second National Conference on Application of Stable Isotopes, Mashhad, Iran, 11 May 2016.

48. Feyzi, D. Traceing Studies in Roudball Dam Site; Iran Regional Water Authorities: Shiraz, Iran, 1998.

49. Saadati, H.; Sharifi, F.; Mahdavi, M.; Ahmadi, H.; Mohseni, M. Determining origin of groundwater recharge resources, drought and wet periods by isotopic tracers in Hashtgerd plain. Manag. J. Range Water Shed 2009, 62, 49-63.

50. Khademi, H.; Mermut, A.; Krouse, H. Isotopic composition of gypsum hydration water in selected landforms from central Iran. Chem. Geol. 1997, 138, 245-255. [CrossRef]

51. Mohammadzadeh, H.; Eskandari, E.; Najafi, M. Studying the stable isotope content of precipitation in Paveh region. In Proceedings of the Second National Conference on Application of Stable Isotopes, Mashhad, Iran, 11 May 2016. 
52. Farpoor, M.; Khademi, H.; Eghbal, M.; Krouse, H. Mode of gypsum deposition in southeastern Iranian soils as revealed by isotopic composition of crystallization water. Geoderma 2004, 121, 233-242. [CrossRef]

53. Parizi, H.S.; Samani, N. Environmental Isotope Investigation of Groundwater in the Sarcheshmeh Copper Mine Area, Iran. Mine Water Environ. 2014, 33, 97-109. [CrossRef]

54. Kalantari, N.; Mohamadi Behzad, H. Investigation source of recharge to Sabzab and Bibi Talkhon karstic springes by application of ${ }^{18} \mathrm{O}$ and ${ }^{2} \mathrm{H}$ stable isotopes. In Proceedings of the 1 st National Conference on Application of Stable Isotopes, Mashhad, Iran, 8 May 2013.

55. Ali, K.K.; Al-Kubaisi, Q.Y.; Al-Paruany, K.B. Isotopic study of water resources in a semi-arid region, western Iraq. Environ. Earth Sci. 2015, 74, 1671-1686. [CrossRef]

56. IAEA/GNIP Global Network of Isotopes in Precipitation (GNIP). Available online: https://www.iaea.org/ servises/networks/gnip. (accessed on 8 November 2019).

57. Porkhial, S.; Ghomshei, M.M.; Yousefi, P. Stable Isotope and Elemental Chemistry of Mt. Sabalan Geothermal Field, Ardebil Province of North West Iran. In Proceedings of the World Geothermal Congress, Bali, Indonesia, 25-30 April 2010.

58. Lehner, B.; Verdin, K.; Jarvis, A. New Global Hydrography Derived From Spaceborne Elevation Data. Eos 2008, 89, 93. [CrossRef]

59. Rozanski, K.; Araguas-Araguas, L.; Gonfiantini, R. Isotopic patterns in modem global precipitation. In Climate Change in Continental Isotopic Records; Swart, P.K., Lohmann, K.C., Mckenzie, J., Savin, S., Eds.; Geophysical Monograph Series; American Geophysical Union: Washington, DC, USA, 1993; pp. 1-36. ISBN 9781118664025.

60. Kalnay, E.; Kanamitsu, M.; Kistler, R.; Collins, W.; Deaven, D.; Gandin, L.; Iredell, M.; Saha, S.; White, G.; Woollen, J.; et al. The NCEP/NCAR 40-Year Reanalysis Project. Bull. Am. Meteorol. Soc. 1996, 77, 437-471. [CrossRef]

61. Asari, A. Source of Salinity at the Plunge of Gar and Barm Firooz Karstic Anticlines; Shiraz University: Shiraz, Iran, 2011.

62. Bagheri Sheshdeh, R. Leakage Potential in Seymareh Dam Site; Shiraz University: Shiraz, Iran, 2007.

63. Masjedi, M.; Jahani, H.; Khalaj Amir hosseini, Y.; Hatami, F.; Kooh Pour, E. Tracer Studies in Seymareh Dam Site in Ilam Province; Iran Water Resources Institute: Tehran, Iran, 1995.

64. Rafighdoust, Y.; Eckstein, Y.; Harami, R.M.; Gharaie, M.H.M.; Griffith, E.M.; Mahboubi, A. Isotopic analysis, hydrogeochemistry and geothermometry of Tang-Bijar oilfield springs, Zagros region, Iran. Geothermics 2015, 55, 24-30. [CrossRef]

65. Ahmadipour, M. reza Karst springs of Alashtar, Iran. Acta Carsolog. 2003, 32, 244-254.

66. Chitsazan, M.; Vardanjani, H.K.; Karimi, H.; Charchi, A. A comparison between karst development in two main zones of Iran: Case study-Keyno anticline (Zagros Range) and Shotori anticline (Central Iran). Arab. J. Geosci. 2015, 8, 10833-10844. [CrossRef]

67. Khalaj Amirhosseini, Y. Application of isotopes and dye tracing methods in hydrology (case study: Havasan dam construction). In Proceedings of the An International Symposium of Isotopes in Hydrology, Marine Ecosystems and Climate Change Studies, Monaco-Ville, Monaco, 27 March-1 April 2011.

68. Mohammadzadeh, H.; Heydarizad, M. Investigating geochemistry and the stable isotope $\left(\delta^{18} \mathrm{O} \& \delta^{2} \mathrm{H}\right)$ composition of Karde Carbonate Lake water (NE Iran). In Proceedings of the 22th Goldschmidt Conference, Monteral, QC, Canada, 24-29 June 2012; p. 2123.

69. Faezi, N. Hydrogeology and Vulenerability Assessment of Ghaleh Dokhtar Spring Catchment Area; Shiraz University: Shiraz, Iran, 2015.

70. Mohammadzadeh, H.; Kazemi, M. Geofluids Assessment of the Ayub and Shafa Hot Springs in Kopet-Dagh Zone (NE Iran): An Isotopic Geochemistry Approach. Geofluids 2017, 2017, 1-11. [CrossRef]

71. Karimi, H.; Raeisi, E.; Bakalowicz, M. Characterising the main karst aquifers of the Alvand basin, northwest of Zagros, Iran, by a hydrological approach. Hydrogeol. J. 2005, 13, 787-799. [CrossRef]

72. Araguás-Araguás, L.; Froehlich, K.; Rozanski, K. Stable isotope composition of precipitation over southeast Asia. J. Geophys. Res. Space Phys. 1998, 103, 28721-28742. [CrossRef]

73. Mashiatullah, A.; Qureshi, R.; Tasneem, M.; Javed, T.; Gaye, C.; Ahmad, E.; Ahmad, N. Isotope hydrochemical investigation of saline intrusion in the coastal aquifer of Karachi, Pakistan. Radioact. Environ. 2006, 8, 382-393.

74. Niroomand, M.H.; Pakzad, M. Studies of Bakhtegan Karstic Water Resources; Karst Research Center of Iran: Shiraz, Iran, 1997. 
75. Zarei, H.; Damough, N.A. Determination the recharge zones of Karstic springs downstram of Karoun3 dam reservoir. In The Fifth Engineering Geology and Enviromental Geology Meeings; Engineering Geology Assossiation: Tehran, Iran, 2007.

76. Mirnejad, H.; Sisakht, V.; Mohammadzadeh, H.; Amini, A.H.; Rostron, B.J.; Haghparast, G. Major, minor element chemistry and oxygen and hydrogen isotopic compositions of Marun oil-field brines, SW Iran: Source history and economic potential. Geol. J. 2011, 46, 1-9. [CrossRef]

77. Ehghahi, M. Traceing Studies of Doupulan Tapeh Karstic Region; Iran Regional Water Authorities: Tehran, Iran, 1990.

78. Pakzad, M. Tracer Studies in Mirza Shirazi (Kovar) Dam Site in Fars Province; Iran Water Research Institute: Tehran, Iran, 1993.

79. Rezaei, M.; Karami, H.; Jokar, B. Studies of Hajiabad Karstic Water Resources; Karst Research Center of Iran: Shiraz, Iran, 2000.

80. Rezaei, M.; Krimi, H.; Jokar, B. Semi Detail Studies of Kazeroun and Persian Gulf Karstic Mega Basin; Karst Research Center of Iran: Shiraz, Iran, 1998.

81. Mohammadzadeh, H. ${ }^{18} \mathrm{O},{ }^{2} \mathrm{H}$, and ${ }^{13} \mathrm{C}$ isotopic compositions of water in Torogh and Kardeh dams, Mashhad. In Proceedings of the Joint European Stable Isotope User Meeting-JESIUM, Presqu'ile de Giens, France, 31 August-5 September 2008.

82. Pakzad, M. Isotopic Studies of Karstic Resources in Kashaf Rood Basin in Khorasan Province; Iran Water Resources Institute: Tehran, Iran, 2000.

83. Mohammadzadeh, H.; Robin, M.; Khanehbad, M. An Investigating of the origin and the groundwater discharge to Bazangan Lake, Eastern Kopet-Dagh Basin-Iran, using geochemistry and stable isotopes approaches. Geochmica Cosmochim. Acta 2008, 72, A641.

84. Lar dam consulting bureau. Tracing Studies in Lar Dam Site; Iran Water Resources Institute: Tehran, Iran, 1983.

85. Mousavi Shalmani, M.A.; Lakzian, A.; Khorasani, A.; Feiziasl, V.; Mahmoudi, A.; Pourmohammad, N. Use of Multiple Linear Regression Method for Modelling Seasonal Changes in Stable Isotopes of ${ }^{18} \mathrm{O}$ and ${ }^{2} \mathrm{H}$ in 30 Pouns in Gilan Province. J. Water Soil 2014, 28, 239-252. 